\title{
Biopharmaceutical and Biosimilar Products in Brazil: From Political To Biotechnological Overview
}

\author{
Angelina M. M. Basso, Maria Fátima Grossi de Sá ${ }^{1}$ and Patrícia B. Pelegrini2* \\ ${ }^{1}$ Embrapa - Genetic Resources and Biotechnology, PqEB Av. W5, Asa Norte, Cx. Postal 02372, Brasília - DF, Brazil \\ ${ }^{2}$ BioLife Brasil Ltda., Distrito Agroindustrial de Formosa, Quadra 01, Lotes 19 e 20, Formosa - GO, Brazil
}

\begin{abstract}
According to the World Health Organization (WHO), one third of the world's population don't have the necessary access to pharmaceutical products, including essential drugs. In Brazil, the Governmental Health System (SUS) distributes some medicaments for free to the population. They were, then, classified into three categories in the country: basic, strategic and specialized components. Among these categories, the last one is highlighted due to the expensive costs of its products, which are essential for the treatment of rare and specific diseases. For this reason, the Ministry of Health created, in 1993, the Program for Specialized Medicaments, where all the drugs included in this category were distributed for free through Clinics and Hospitals. During the first year of this Program's implementation, there were 15 different items distributed into 31 distinct presentations. Nowadays, the list expanded to 150 different items dispensed into 310 presentations. Hence, the availability of imported pharmaceutical products in Brazil overloaded the expenses by the Brazilian Ministry of Health. Only during 2011, US\$1.5 billion were spent on these products, where $30 \%$ of this amount was related to specialized ones. In order to reduce costs, the Brazilian Federal Government developed, in 2004, the Technological Innovation Law. According to the Decree number 6.041, the National Politics for Biotechnology and the National Committee of Biotechnology were created in order to stimulate the development of Biotechnology for human health, targeting mainly the national production of biopharmaceuticals. Furthermore, the end of patents for several medicaments during the last 5 years enhanced the motivation for national production of new drugs. In this way, some Governmental Institutions, in partnership with International Pharmaceutical Industries, started developing the first biosimilar molecules. Therefore, this report describes the evolution of Biotechnology in Brazil, relating the laws, regulations and Programs created along the last 20 years for Human Health application.
\end{abstract}

Keywords: Brazil; Biotechnology; Biopharmaceuticals; Biosimilars; Regulations

\section{Introduction}

The use of pharmaceutical compounds for treatment of several diseases has been described for more than 3000 years. However, only during the last century that pharmaceuticals started being produced in large scale by the properly named "Pharmaceutical Industries". Improvements in science, such as the discovery of penicillin for production of antibiotics, and advances on recombinant DNA (rDNA) and hybridome allowed the development of Biotechnology and new techniques applied on the production of more efficient pharmaceuticals.

Nowadays, the production of biological medicaments occurs by companies with Biotechnology application and also by traditional pharmaceutical industries, or even by a partnership between them. For example, companies such as Amgen, Novartis, Abbot, Roche and Genentech produce the 10 most selling drugs worldwide, including medicaments developed through rDNA technology (Aranesp, Enbrel, Epogen, Erypo, Neulasta), as well as through hybridome technology (Avastin, Herceptn, Humira, Mabthera, Remicade) [1]. Therefore, the increase on the production of biopharmaceuticals is exponentially increasing every year. The emerge of biosimilars due to the expiration of many patents also opened the market for the entrance of new companies. In this way, each country has been developing guidelines and regulations for the approval of biological biosimilar drugs [2].

Hence, in 2009, Brazil was the $10^{\text {th }}$ biggest buyer of pharmaceutical products in the world. Hence, the main cause for the increase of Brazilian Pharmaceutical Industries was the Law 9.787/99 that established the sale of generics in the country [3]. In similar ways, the increasing of Brazilian Biopharmaceutical Industries has been grown due to investments by the Government for national production of such medicaments, as well as due to the enhancement of partnerships between Public Research Institutions and Private Companies. Only until 2008, there were 12 Biopharmaceutical companies registered at ANVISA, 8 of each where national ones: Aché, Blausiegel, Cristália, Eurofarma, Fiocruz, Prodotti and Silvestre Lab [4].

Moreover, the increasing expenses by the Ministry of Health with imported medicaments have motived the Government to invest on the national production of many biosimilar drugs. In 2011, the Brazilian Government spent US $\$ 4.9$ billion on the importation of medicaments [5], and among them, 8 biopharmaceuticals imported represented $18 \%$ of the total costs, including: philgastim, glucagon, growth hormones, human recombinant insulin, $\alpha$-interferon, $\beta$-interferon and somathrophin. For this reason, the development of biosimilar molecules in Brazil can be seen as a strategy for the improvement of Brazilian Biopharmaceutical Industries. In addition, the market for pharmaceuticals worldwide is estimated to grow $15 \%$ by 2015 , which means that sales can go up to US\$ 182.5 billion [6].

*Corresponding author: Patrícia B. Pelegrini, BioLife Brasil Ltda., Distrito Agroindustrial de Formosa, Quadra 01, Lotes 19 e 20, Formosa - GO, Brazil, E-mail: patrícia@biolifebrasil.com.br

Received November 30, 2012; Accepted December 26, 2012; Published December 31, 2012

Citation: Basso AMM, Grossi de Sá MF, Pelegrini PB (2013) Biopharmaceutical and Biosimilar Products in Brazil: From Political To Biotechnological Overview. J Bioequiv Availab 5: 060-066. doi:10.4172/jbb.1000135

Copyright: @ 2013 Basso AMM, et al. This is an open-access article distributed under the terms of the Creative Commons Attribution License, which permits unrestricted use, distribution, and reproduction in any medium, provided the original author and source are credited. 
Furthermore, in Brazil, the debate about the establishment of general regulations for biological medicaments is a recent concern, which can be seen, for example, by the Public Consultancy number 49/2010 proposed by ANVISA. As the RDC number 315/2005 does not contemplate the requirements needed to guarantee the comparison between biosimilar products, the Public Consultancy created new strategies to overcome this flaw.

Hence, in order to assure the biosafety and efficacy of new biological medicaments, the Public Consultancy is discussing novel proceedings, tests and documents necessary for the registration of such products. Among the proposals, there is the possibility that companies might be able to develop biosimilar drugs by performing clinical comparison evaluations with the original product. In some cases, it is possible to extrapolate the therapeutic use of some biosimilar products to other therapeutic uses. For this, there is the need of proving that the data obtained for one disease cannot interfere with the activity of the same molecule for the second disease [7]. Furthermore, the number of tests required can be reduced, considering the purpose of use for the molecule, but only after inspection and case-by-case analysis by ANVISA.

Therefore, in this review, the Political and Biotechnological aspects of Biopharmaceuticals and Biosimilar in Brazil will be described, focusing on the attempts for the country to become independent on producing national medicaments.

\section{Biopharmaceuticals and biosimilars}

Biopharmaceuticals are featured as important tools for commercial and health clinical areas, and are now changing the pharmaceutical profile, not only for Brazilian industries but worldwide. Examples of these products are monoclonal antibodies and recombinant endogenous proteins [8]. Hence, it is expected that, by 2015, more than $50 \%$ of the new approved drugs are from biological origins, and this percentage is estimated to increase up to $75 \%$ by 2025 [9].

Therefore, biopharmaceuticals are characterized as drugs whose essential substances are obtained from live organisms or their derivatives, through biotechnological processes. All products obtained from this technology present higher complexity when compared to traditional chemical drugs. This occurs due to many variables applied to pharmaceuticals, such as selection of an expression system or synthesis, cell growth conditions, purification processes; need to handle glycosylation, phosphorylation, metilation, and storage environment [10].

However, due to the heterogeneity of biopharmaceuticals, they are more sensitive than other traditional chemical drugs, which can affect their stability and integrity, as opposed to traditional drugs that are smaller and easier to manipulate and control [11-13]. In contrast to traditional drugs, biopharmaceuticals are immunogenic molecules. Nevertheless, it is important to highlight that subtle differences at the structure of these biopharmaceuticals might lead to major differences in the immunogenic reactions [14].

In addition, biosimilar compounds comprehend pharmaceuticals that arose after the expiration of many biopharmaceuticals patents, once that they are copies of the original drug molecules. Nowadays, they are being developed by several pharmaceutical companies and are commercialized in the market for over 25 years [8]. The main characteristic of a biosimilar drug is that the method used for the acquisition of its compound is different from the process utilized for the development of a biopharmaceutical drug, even when both produce identical molecules with the same biological activity. This feature was established by Regulatory Agencies, such as the European Regulatory Agency, which determined biosafety rules for the development of biosimilars $[15,16]$. When the biological activity of a biosimilar is not the same as the original product, it becomes inadequate for quality, efficacy and security evaluations, requiring further analyze on bioavailability and bioequivalence of this molecule [10,17]. In Europe, the guidelines addressing the requirements for quality control and production of a biosimilar were initiated in 2005, and the most recent edition of these guidelines was approved by the Committee of Medical Products for Human Use in 2006 [18]. Moreover, during 2009, around 75\% of all prescribe pharmaceutical products in U.S. were generic drugs [19]. Hence, both generic and biosimilar drugs spread in the market with the purpose of decreasing the final price of pharmaceutical products.

Furthermore, generic drugs encompass all molecules that contain the same active principle, pharmaceutical formula, dose, administration route, with the same reference for therapeutical purpose and safety [20]. In Brazil, the release of these medicaments into the market brought an increase on the competition between pharmaceutical products [21]. Hence, the reduced costs of these drugs are mainly related to cheap expenses on the production of these molecules, low costs for clinical evaluations, as well as less investments on marketing [22-24]. According to the Brazilian Regulatory Agencies for pharmaceutical products, the Brazilian Agency for Sanitary Vigilance - ANVISA, during 2003, there was $40 \%$ reduction on the price of pharmaceuticals after the introduction of generic drugs into the market [25]. Furthermore, public politics developed in Latin America countries are aiming the motivation for the acquisition of good-quality pharmaceuticals that are also cheap for the population $[24,26]$.

\section{Brief history about biopharmaceuticals in Brazil}

The access to pharmaceutical products is essential to guarantee the constitutional right to health for each person in the population. According to the World Health Organization (WHO), one third of the world population does not have access to regular and essential pharmaceutical products [21,27]. In Brazil, The Ministry of Health, through the Unique Health System (SUS), offers the acquisition of drugs for the population free of charge. These drugs, as described at the Brazilian law Portaria GM/MS no 2.891 - of November 26, 2009 - are classified into three categories: basic, strategic and specialized components $[28,29]$. These drugs were initially approved as part of the National Politics on Pharmaceutical Assistance by the Ministry of Health's department, SUS [30].

Among these categories, the specialized medicines are detached, once that they are drugs whose cost is extremely high, restricting their acquisition by many patients. Therefore, in order to solve this problem, the Brazilian Federal Government developed, in 1993, the Program for Specialized Drugs. Besides providing high-cost drugs to the population for free, the Program included the availability of pharmaceutical products used on the treatment of long-term diseases. The same program, during that year, had included 15 medicines available into 31 different pharmaceutical presentations [31]. Nowadays, the list presents 150 items under 310 different pharmaceutical presentations [32], which attend a demand of millions of patients with several diseases, including, kidney insufficiency, viral hepatitis, Alzheimer's disease, AIDS, multiple sclerosis and diabetes.

However, Brazil is not the only country affected by the continuous increase of costs related to pharmaceutical products. An international estimative presented at the Global Forum for Health Research in 2006 , 
indicated that health issues corresponded to $20 \%$ of the total world expenses from private and public sectors, and whose activities in Technological Research and Development clearly showed to be one of the most world dynamic areas [33].

The continuous increase of cost with pharmaceutical products in Brazil demonstrates the alarming expenses with the acquisition of diverse drugs along the years (Figure 1) [5]. In 2007, a study showed that there was a big difference between the costs the Government spent with services at health department (9.6\%) and the budget expended with the purchase of medicaments (123.9\%), during the years of 2002 and 2007 [34]. The enhancement of expenditures with pharmaceutical products also occurred in other countries around the world, such as Great Britain and Canada, where the amount spent with drugs increased $10 \%$ and $6 \%$, respectively [34]. Moreover, in the United States, it is estimated that the expenses referring to medicaments will grow from US\$ 184 billion in 2003, to US\$ 519 billion in 2013 [31]

During 2009, the Brazilian Government spent US\$ 1.3 billion only on the purchase of the pharmaceutical drugs classified in the specialized group. And, during the year of 2010, the total cost reached more than US\$ 1.6 billion. Until the month of April of 2011, the total amount expended with the drugs from the specialized group was already US\$ 1.5 billion [5].

Hence, the fact that Brazil is dependent on acquiring many pharmaceutical medicaments important for chronic and severe diseases reflects directly on its public health and on the balance of trade. Nevertheless, the Brazilian Government is now supporting the development of products that can aggregate value and technology to the country. The first encouragement started in 2004, with the release of the Technological Innovation Law number 10.973 (from December $2^{\text {nd }}$ of 2004), where the development of innovative processes and products by Brazilian Companies was incentivized, and increasing intercompetition in the country [33]. Nowadays, the Brazilian Government invests in companies that present the technology to produces all kinds of medicaments, wagging on the strategic ways of biotechnology and on the decrease of costs with such products [35]. Therefore, Brazil could become, over the years, one of the biggest biopharmaceutical components' producers, supplying the internal demand of the main needed drugs.

\section{Expired patents and biopharmaceutical medicines}

The need of producing proteins with therapeutic activity in large scale arose during the Second World War, when there was a pronounced search for proteins derived from blood [36]. The definition of "Biodrugs" was, then, referred to these therapeutic recombinant proteins developed using biotechnological tools [37]. The importance of biodrugs, or better saying, biopharmaceutical products, is evident, however, many proteins with therapeutic activity were purified from animal sources, resulting in potential allergenic risks to human health.

In this way, the first biopharmaceutical molecule produced, insulin was obtained through the purification of animal pancreas [37]. At the moment, these molecules are produced through techniques involving biotechnology, resulting in more efficient and safe compounds.

Recently, some biopharmaceutical components already in the market started showing their patents expiring [38]. Hence, the world's sales leader, Lipitor ${ }^{\circledR}$ (Pfizer) - where US\$ 13 billion of this product was sold only during the year of 2009 - had its patent expired on 2011 [39]. Along these lines, with the increase of patent expiring drugs, a new race for development of second generation products, now denominated biosimilars (similar medicaments) or generics (identical medicaments, but identified with the name of the main active principle) are widely on expansion $[40,41]$.

According to the European Legislation (2004/27/EC), biosimilars are distinct from generics by their size, complexity and stability, once that they need to be evaluated individually through pre-clinical and clinical assays, including pharmacy-vigilance analyses. During 2005 and 2006, the regulatory authorities from the EMEA's Committee of Human Medical Products published a specific guide for biosimilars, whose focus was to evaluate the security and efficacy of these molecules [42]. The mode by which biosimilars and generics can replace the original pharmaceutical compounds varies among countries, but the main difference is their price [43]. In Brazil, all the patents of medical components are made under the Intellectual Property Code - CPI/96, which introduced the concepts of patents in pipeline and patents under revalidation. These patent types were made in order to introduce the lack of procedures for patents created for chemical, pharmaceutical and food products /processes, not available at the earlier legislation (art. 230 and 231 of Law number 9.279/96) [44].

The generics achieved the Brazilian market through the "Generic Law" (9.787/99), where it was established that these medicaments would have to be $40 \%$ cheaper than the original pharmaceutical medicines. Nowadays, $14 \%$ of all drugs sold in Brazil are generic ones [21]. Any pharmaceutical company can produce, distribute and commercialize medicaments, once that they in accordance with ANVISA rules [39]. Therefore, ANVISA elaborated, in December of 2010, through the RDC number 55, new rules for the registration of similar medicaments, using the comparison factor with other similar biological drugs [45]. Earlier, in 2005, the European Agency of Medicine (EMEA) had already issued a series of outlines for the law established by the European Union, which instituted scientific patterns for the assistance of laboratories during the process of biosimilars approval [7].

Furthermore, the appearance of Creutzfeldt-Jacob disease, in patients that received growth hormones from the hypophase of corpses, stimulated the research for the development of a new recombinant hormone. Then, the hormone somathropin known as Omnitrope (Sandoz Biopharmaceuticals), was the first biosimilar to be released

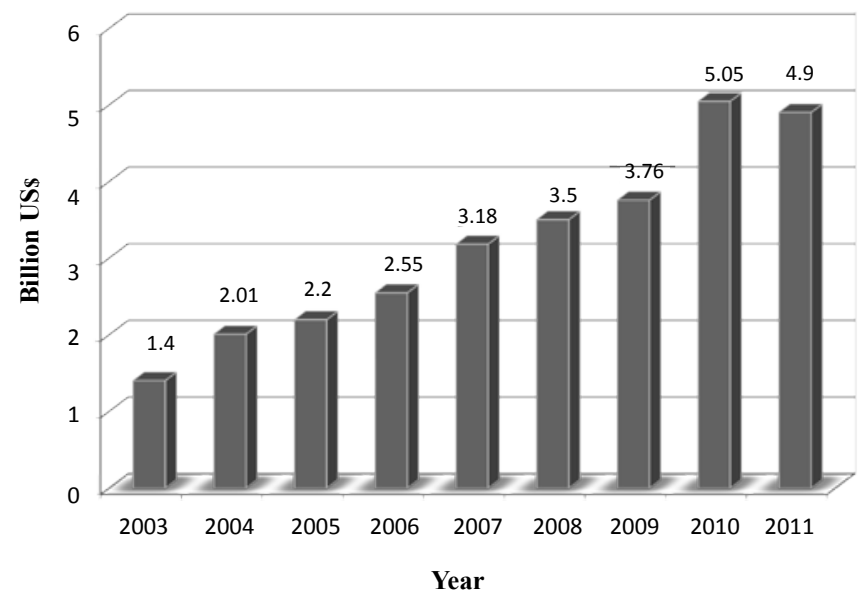

Figure 1: Annual expenses of the Ministry of Health with the acquisition of imported medicaments from years of 2003 until April 2011. Modified from [5] 
into the market by European regulatory agencies, in April of 2006 [46]. However, some biosimilar molecules caused side effects, such as the production of antibodies against the drug, including insulin, anti-TNF (tumoral necrosis factor), recombinant VIII factor and erythropoietin. Although the recombinant protein hormone be similar to the endogenous hormone in humans, three patients demonstrated production of antibodies against both exogenous and endogenous proteins, resulting in the loss of tolerance by their immune systems $[47,48]$. Nevertheless, does is no information in literature that indicates which side effects are stronger with the administration of biosimilar molecules, when compared to other traditional drugs. In this way, rigid analyses of each biosimilar and their effects should be performed individually before being put for approval under the regulatory authorities [10,38,49]. Nowadays, more than 350 pharmaceutical drugs, produced through biotechnology techniques and directed to the treatment of autoimmune diseases, infectious diseases and cancer, are at approval stage [37]. The most important biopharmaceutical products are shown in table 1 .

Moreover, in Brazil, the Government elaborated the Politics for Biotechnology Development, through the Decree 6.041 (February, 8 of 2007), which incentivized Brazilian companies to produces national biosimilar molecules in order to reduce costs of medicaments and strengthen the bioindustry of the country [33]. Hence, the production of biopharmaceutical and biosimilar components by a Brazilian Biotechnology company it of extreme importance for the country, once that it will establish an alternative path, instead of the acquisition of high cost important medicaments.

\section{Patents in pipeline and medicaments}

The most important way to guarantee the exclusivity of industrial and pharmaceutical properties is through patents. The term 'patent' maintains a temporary prevention so that other competitors do not copy or sell the respective product in an inferior price than the original one. This permits that the invention or industrial creation becomes a profitable investment [50].

On March 19, 1474, it was promulgated, in Venice, the first Law for patents, which came from the need of commercial relations between cities, states and medieval kingdoms. In Brazil, the first granted patent occurred in 1752, for a machine that presented the ability to peel rice. Nevertheless, the first Brazilian law for patents was only enacted six decades later, with the prince's charter - D. João VI - in April 28, 1809. After the first Brazilian patent, a series of new laws and decrees were made along the years, in order to improve or revoke some benefits [51]. Among them, in 1971, a federal autarchy bound to the Ministry of Development, Industry and Foreigner Commerce created through the law number 5.648: the National Institute for Industrial Property - INPI. The purpose of this Institute was to register brands, marks, computer

\begin{tabular}{|c|c|}
\hline Molecules & Application \\
\hline Hormones & Diabetes, First Aids \\
\hline Growth Factor & Anemia \\
\hline Interferons & $\begin{array}{l}\text { Leukemias, Multiple sclerosis, Hepatitis } \\
\text { C }\end{array}$ \\
\hline Monoclonal Antibodies & Several diseases \\
\hline Vaccines & $\begin{array}{l}\text { Disease Prevention (Dengue, } \\
\text { Tuberculosis) }\end{array}$ \\
\hline $\begin{array}{l}\text { Others (Therapeutical Enzymes, Tumor } \\
\text { Necrosis Factors) }\end{array}$ & $\begin{array}{l}\text { Auto-immune diseases, Rheumatoid } \\
\text { arthritis }\end{array}$ \\
\hline
\end{tabular}

Table 1: Medicaments most required for national production. Adapted from [37].
Programs, industrial designs, geographic indications, integrated circuit topographies and patent granting [50].

The law number 9,279, from May 14, 1996, aimed to attend the requirements of the 'Agreement about Aspects of Intellectual Property Rights Related to Commerce' and introduced the term patents in pipeline. This mechanism allowed the application for patents related to processes and substances, pharmaceutical and chemical products, in order to give a guaranteed protection of the patent in the country and outside it [51]. Hence, patents in pipeline aim on bringing them directly to the Brazilian law system, whether the patent was applied in Brazil or in other countries [44].

After the application for patent in pipeline, analysis and permission from INPI, the real patent is finally granted. In the case of a foreign product, the patent is granted on the same way it was granted in the original country, provided the location where the patent allowance was applied. The patent term of these products starts from the date it was deposited in the country and is valid for twenty years inside Brazil [44]

Some pharmaceutical products were already benefited with the law for patents in pipeline. Among them, there is Viracept ${ }^{\circledR}$, a medicament produced by Roche, which had this law used to guarantee the patent of the respective drug on March 71997 in Brazil, although the original deposit occurred at the United States in 1993 [51]. However, it is also common to observe pharmaceutical products that were not benefited by this law of pipeline and, consequently, lost their patents. The most famous example is the case of Viagra ${ }^{\circledR}$ (Pfizer), which remained twelve years on Brazilian market until it patent be revoked, in 2010, by the Brazilian Law Superior Court. Nowadays, at a price $60 \%$ cheaper, this drug is produced as a generic medicament by EMS Company [52].

\section{Biopharmaceuticals and biosimilars in Brazil}

Although the sales of generics in Brazil are growing continuously, the expiration of patents has led the Government to encourage the development of biosimilar drugs in the country. Hence, in 12 May 2008, The Executive Group of the Industrial health Complex (GECIS) was implemented in order to auxiliate on the analysis of the health sector, highlighting the deficiencies and limitations related to technology development of novel drugs. However, the publication of an Official report approved by the Chamber of Deputies of Brazil on December 2011, and the Report approved by the Special Subcommittee for the Development of Complex Industrial health, Drug Production, Equipment and Other Supplies (SSD Report) still intensely underlined the high cost of imported pharmaceutical products, emphasizing the deficits on domestic production [53].

At the same time, during 2011, The Brazilian Agency for Sanitary Vigilance (ANVISA) issued four guidelines for biosimilar products. Moreover, it created a technical chamber for biologics and released some regulations for registration and post-registration of biosimilars in Brazil. In 2012, it is expected that ANVISA publishes new guidelines, specific for the production of monoclonal antibodies [54].

The incentive for national production of biosimilar molecules has attracted not only local companies, but also International Industries. The Ministry of Health elaborated a list containing the name of several strategic and specialized drugs that were primordial for national production. In addition, the Brazilian Government used the strategy of Partnerships for productive development (PDPs) to utilize the acquisition of medicaments as an industrial policy alternative. Therefore, the Ministry of Health recommended partnerships between Governmental Research Institutes and private industries, in order of 
transferring technologies, increasing the biopharmaceutical industry of Brazil and, most important, contributing for the decrease of costs on the acquisition of such medicaments [53]. By that time, around 30 contracts were made between public and private industries, some of which have already started producing biosimilar molecules and, until now, a number of initiatives are already in the pipeline [55].

Among the PDPs, some molecules developed during the partnership have demonstrated consistent data for technology transfer. Farmanguinhos, the biggest public Research Institute of Brazil, has established protocols for the development of three biopharmaceutical products, including: (i) the antiretroviral Atazanavir, in partnership with Bristol-Myers Squibb; (ii) the immunosuppressant Mycophenolatemofetil, together with Roche, and; (iii) Pramipexole, a medicament for Parkinson's disease, technologically advanced with Boehringer. The Pharmaceutical Laboratory of Pernambuco State (LAFEPE), in collaboration with MerckSharp and Dohme, has also developed an antiretroviral denominated Raltegravir, which is in process of technology transfer $[53,55]$.

In 2009, two biosimilars medicaments used as therapeutical agents in rheumatology diseases, and produced by international companies, have already reached local market, such as Enbrel ${ }^{\mathbb{}}$ (etanercepte; PfizerWyeth) and Mabthera ${ }^{\circledR}$ (rituximabe; Roche) [56]. Other foreigner corporations, such as AMGEN, has incorporated some companies and licensed products, such as Hypermarcas, in January of 2011, and Bergamo, in April of 2011 for the commercialization of medicaments in Brazil. Furthermore, Novartis has announced the local development of vaccines against meningococcal $\mathrm{B}$ using genetically modified plant for the next three years [57].

Nevertheless, the lack of patent rights for medicines acquired through public/private companies has led the Brazilian Government to stimulate the partnership between Brazilian companies. Therefore, recently, the Brazilian Laboratory BioNovis was created to initiate the local production of biosimilar drugs. BioNovis was settled with the partnership between four National companies (Aché, EMS, Hypermarcas and União Química), and will focus on the production of biosimilar drugs included in the lists of strategic and specialized medicaments [58].

Some Brazilian Universities are also investing on the development of biosimilar molecules, using different expression systems. Hence, the first report obtained from academic studies of biosimilar molecules was published by researches from the Catholic University of Rio Grande do Sul (PUCRS), located at the South of Brazil. There, the human granulocyte and macrophage colony stimulating factor (hGM-CSF) was cloned, expressed in bacterial system, purified and assayed using TF-1 cells [59]. The results showed that Brazil not only possesses the technology to develop its own biosimilar molecules, but also presents well trained and expert local professionals already working in this field.

The use of bacterial systems was also utilized for the expression of other molecules important for human health. Hence, the lysosomal glucocerebrosidase (GCR), an enzyme related to Gaucher's disease, was successfully expressed in Escherichia coli cell lines by researches from the Biotechnology Centre of Butantan Institute. The purified recombinant enzyme was used for the immunization of BALB/c mice for antibody production, demonstrating an easy alternative for GCR heterologous production [60]. Later, researchers from the same institute developed a methodology for optimized expression and purification of the mutant human granulocyte colony stimulating factor (hG-CSF), biosimilar to the molecule from the current commercial drug Nartograstim. High levels of protein expression was observed using bacterial systems and the purified recombinant hG-CSF showed acceptable structure integrity and biological activity when compared to the mutant version of hG-CSF (Nartograstim). Apart of the effective evaluation of rhGCSF as a therapeutic agent for neutropenia, it was also successfully used for the production of polyclonal antibodies in mice [61]. Recently, a study evaluating the comparison of two treatments for patients with Hepatitis C Virus (HCV) genotypes 2 and 3 of infection, using a biosimilar standard alpha-interferon (IFN) plus ribavirin (RBV) and the second one using pegylated interferon (Peg-INF) plus RBV, was performed by researchers from the State University of Campinas (Unicamp). In this study, it was observed that the treatment with PegINF was more efficient on causing sustained virological response (SVR) in the patients analyzed than when the biosimilar INF was applied, concluding that, in this case, the biosimilar molecules was not the best option for the treatment of patients with HCV genotypes 2 and 3 [62].

The latest finding until now is the expression and purification of a recombinant peptide glucagon, using bacterial systems. The commercial glucagon is included in the list of specialized drugs by the Ministry of Health and the recombinant peptide showed amino acid sequence and structure identical to the original molecule, with increased activity in in vivo assays, when compared to the commercial products [63]. Hence, it is a potential molecule that could be applied for several treatments, such as hypoglycemia, diabetes and alcoholic coma.

\section{Conclusion}

Brazil is exponentially increasing the investments and technologies on the development of local biosimilars that could be used, in a near future, for the production of novel medicaments for the treatment of several diseases. This is also leading the enhancement of national companies specialized on biosimilar molecules, as well as partnerships between public research institutes and international private corporations. Nevertheless, Brazil is still far from being 100\% independent from the importation of biopharmaceutical products, as only an insignificant percentage of drugs is produced in the country. Moreover, other developing countries, such as China, India, Cuba and Korea, already present well-structured companies that are producing biosimilar medicaments with high quality and efficiency, which makes it more difficult for Brazil to highlight in the international market. Therefore, the initial attempt of brazilian companies is to supply the local demand for drugs, in order to collaborate for the decrease of costs by the ministry of health on purchasing important pharmaceutical products. Furthermore, the regulations and guidelines published by ANVISA and other Government Offices for biosimilars do not comprise all the necessary requirements for an effective evaluation of these molecules yet. There is a lot to learn and to be changed in the laws, on how to proceed for the adequate release of a final medicament containing a biosimilar product in the country. However, Brazil has a high potential of becoming one of the biggest producer of biopharmaceuticals - including biosimilars - in America for the next decade to come, as the technology has being settled, great amount of money has been invested by the government and there is a diverse group of competent research teams working on it.

\section{References}

1. Reis C, Capanema LXL, Filho PLP, Pieroni JP, Barros JP, et al. (2009) Biotecnologia Para Saúde Humana: Tecnologias, Aplicações e Inserção na Indústria Farmacêutica. BNDES Setorial.

2. Rader $\mathrm{R}$ (2007) What is a generic biopharmaceutical? Biogeneric? Follow-on protein? Biosimilar? Follow-on biologic? Bioproc Int 1: 20-28. 
Citation: Basso AMM, Grossi de Sá MF, Pelegrini PB (2013) Biopharmaceutical and Biosimilar Products in Brazil: From Political To Biotechnological Overview. J Bioequiv Availab 5: 060-066. doi:10.4172/jbb.1000135

3. Gadelha C (2009) Perspectivas de Investimento em Saúde. Relatório Integrante da Pesquisa "Perspectivas do Investimento no Brasil", em parceria com o Instituto de Economia da UNICAMP, financiada pelo BNDES. Rio de Janeiro, UFRJ.

4. Padilha G, Kropf M, Baetas R (2009) Biomedicamentos: copiar é uma estratégia viável para o Brasil? In: Gadelha C, Política de Inovação em Saúde. (1stedn), Projeto FIOCRUZ-FIOTEC-OPAS, Rio de Janeiro.

5. Gadelha C (2011) Seminário Valor Econômico Perspectivas do Setor Saúde no Brasil. A perspectiva do Complexo Industrial da Saúde: o Desenvolvimento Industrial e Científico do Setor e Rumos para a Assistência Farmacêutica.

6. Market Publishers (2010) Biopharmaceuticals - A Global Market Overview. Drugs \& Biotechnology

7. Agency of European Medicines (2005) Evaluation of Medicines for Human Use. Guideline on Similar Biological Medicinal Products.

8. Berkowitz SA, Engen JR, Mazzeo JR, Jones GB (2012) Analytical tools for characterizing biopharmaceuticals and the implications for biosimilars. Nat Rev Drug Discov 11: 527-540.

9. Erickson BE (2010) Untangling biosimilars. Chem Eng New 88: 25-27.

10. Declerck PJ (2012) Biologicals and biosimilars: a review of the science and its implications. Gen Bios Int J 1: 13-16.

11. Crommelin DJ, Storm G, Verrijk R, de Leede L, Jiskoot W, et al. (2003) Shifting paradigms: biopharmaceuticals versus low molecular weight drugs. Int J Pharm 266: 3-16.

12. Crommelin D (2005) Pharmaceutical evaluation of biosimilars: important differences from generic low-molecular-weight pharmaceuticals. Eur J Hosp Pharm Sci 11: 11-17

13. Sekhon BS, Saluja V (2011) Biosimilars: an overview. Biossimilars 1: 1-11

14. Sauerborn M, Brinks V, Jiskoot W, Schellekens H (2010) Immunologica mechanism underlying the immune response to recombinant human protein therapeutics. Trends Pharmacol Sci 31: 53-59.

15. Agency of European Medicine (2006) Guideline on similar biological medicina products.

16. Declerck PJ (2007) Biotherapeutics in the era of biosimilars: what really matters is patient safety. Drug Saf 30: 1087-1092.

17. Woodcock J, Griffin J, Behrman R, Cherney B, Crescenzi T, et al. (2007) The FDA's assessment of follow-on protein products: a historical perspective. Nat Rev Drug Discov 6: 437-442.

18. Haddadin RD (2011) Concept of biosimilar products in Jordan. Biologicals 39 : 333-335

19. Kozlowski S, Woodcock J, Midthun K, Sherman RB (2011) Developing the nation's biosimilars program. N Engl J Med 365: 385-388.

20. Lopes DM, Néri ED, Madeira Ldos S, Souza Neto PJ, Lélis AR, et al. (2012) [Analysis of similar drug labeling: potential medication errors]. Rev Assoc Med Bras 58: 95-103.

21. Blatt CR, Trauthman SC, Schmidt EH, Marchesan S, da Silva L, et al. (2012) General awareness and use of generic medication among citizens of Tubarão. State of Santa Catarina, Brazil 17: 79-87.

22. Dias CRC (2003) Medicamentos genéricos no Brasil de 1999 a 2002: análise da legislação, aspectos conjunturais e políticos [dissertação]. Faculdade de Saúde Pública. Universidade de São Paulo -USP.

23. Dias CR, Romano-Lieber NS (2006) [Generic drug policy implementation in Brazil]. Cad Saude Publica 22: 1661-1669.

24. Tobar $F$ (2008) Economía de los medicamentos genéricos em America Latina. Rev Panam Salud Publica 23: 59-67.

25. Vecina NG (2003) Remédio bom e barato. Ministério da Saúde, Anvisa Pública.

26. Bueno CS, Moreira AC, Oliveira KR (2012) [Cost of drugs used to treat cardiovascular disease in Brazil]. Rev Panam Salud Publica 31: 62-67.

27. Nwobike JC (2006) Empresas farmacêuticas e acesso a medicamentos nos países em desenvolvimento: o caminho a seguir. Sur - Ver Int Dir Hum 3 126-143.

28. Vieira FS (2010) Assistência Farmacêutica no Sistema Público de Saúde no Brasil. Rev Panam Salud Pub 27: 149-156.
29. Publio RN (2011) Análise de solicitações de medicamentos excepcionais prescritos aos usuários de planos privados de saúde no estado de Minas Gerais [dissertação]. Universidade Federal de Minas Gerais - UFMG.

30. BRASIL. Ministério da Saúde (2006) Portaria 2.577/GM de 27 de Outubro de 2006.

31. Claudia MC, Fabíola SV, Carlos VG, Paola Z (2011) Medicamentos de Dispensação Excepcional: histórico e Gastos do Ministério da Saúde do Brasil. Ver Saúde Pub 45: 233-240.

32. BRASIL. Ministério da Saúde (2012) Portal da saúde. Componentes especializados da assistência farmacêutica.

33. Integra Brasil (2011) Agência de Integração à Saúde, Meio Ambiente e Desenvolvimento Social do Brasil. III Fórum Nacional Sobre Inovação e Tecnológica na Área de Saúde no Brasil.

34. Vieira FS (2009) Gasto do Ministério da Saúde com medicamentos: tendência dos programas de 2002 a 2007. Ver Saúde Pub 43: 674-681.

35. Pimenta CG (2008) O ambiente institucional da biotecnologia voltada para a saúde humana no Brasil [dissertação]. Universidade de Brasília - UnB.

36. Walls D, McGrath R, Loughran ST (2011) A digest of protein purification Methods Mol Biol 681: 3-23.

37. Ferro ES (2010) Biotecnologia Translacional: hemopressina e outros peptídeos intracelulares. Estudos Avançados 24: 109-121.

38. Azevedo VF (2010) Estamos preparados para prescrever biossimilares? Ver Bras Reumat 50: 221-224.

39. Barreiro EJL, Pinto AC (2010) Generic Pharmaceutical Drugs: Import Them, till when? J Braz Chem Soc 21: 776.

40. Niederwieser D, Schmitz S (2011) Biosimilar agents in oncology/haematology: from approval to practice. Eur J Haematol 86: 277-288.

41. Utzig MFK, Virtuoso S, Oliveira SMM (2010) Verification of the adhesion of community to generic medicines after seven years of implantation of the law. Visão Acadêmica 10: 100-105.

42. Busch AB, Lehman AF, Goldman H, Frank RG (2009) Changes over time and disparities in schizophrenia treatment quality. Med Care 47: 199-207.

43. Rosenberg G, Fonseca MGD, d'Avila LA (2010) Análise Comparativa da Concentração Industrial e de Turnover da Indústria Farmacêutica no brasil para os segmentos de medicamentos de Marca e Genéricos. Econom Soc 19: $107-134$

44. Barbosa DB (2006) Inconstitucionalidade das Patentes Pipeline.

45. ANVISA - Agência Nacional de Vigilância Sanitária (2010) RDC n. 55, 16 de Dezembro de 2010.

46. Vanz ALS (2008) Clonagem, superexpressão, purificação e caracterização da proteína recombinante humana fator estimulador de colônias de granulócitos [dissertação]. Pontifícia Universidade Católica do Rio Grande do Sul - PUCRS.

47. Thorpe R, Swanson SJ (2005) Current methods for detecting antibodies against erythropoietin and other recombinant proteins. Clin Diagn Lab Immuno 12: $28-39$

48. Lee H, Yang J, Kim H, Kwon JW, Oh KH, et al. (2010) Improvement in erythropoieis-stimulating agent-induced pure red-cell aplasia by introduction of darbepoetin- $\alpha$ when the anti-erythropoietin antibody titer declines spontaneously. J Korean Med Sci 25: 1676-1679.

49. Calderon BD, Escalante IMM (2010) Medicamentos e Biossimilares controvérsias científicas y legales. Farmacia Hospitalaria 34: 29-44

50. (2011) INPI - Instituto Nacional de Propriedade Industrial.

51. Filho SB (2006) Pesquisa e Desenvolvimento de Fármacos no Brasil: estratégias de Fomento [dissertação]. Universidade de São Paulo - USP.

52. BRASIL. Ministério Público do Estado do Paraná (2010) Fim de patente do viagra anima farmacêuticos.

53. Licks OB (2011) Generics and biosimilars in Brazil: elements of the industria policy of the Brazilian government. Leonardos \& Licks Advogados. Practical Law Publishing Limited and Practical Law Company, Inc. 
Citation: Basso AMM, Grossi de Sá MF, Pelegrini PB (2013) Biopharmaceutical and Biosimilar Products in Brazil: From Political To Biotechnological Overview. J Bioequiv Availab 5: 060-066. doi:10.4172/jbb.1000135

54. Castanheira LG, Barbano DP, Rech N (2011) Current development in regulation of similar biotherapeutic products in Brazil. Biologicals 39: 308-311.

55. FIOCRUZ - Fundação Oswaldo Cruz (2011).

56. Simoens S (2009) Health economics of market access for biopharmaceuticals and biosimilars. J Med Econ 12: 211-218.

57. Franco V (2012) Brazilian Government Encourages the Development of Biosimilar Drugs, According to New Market Research.

58. Azevedo VF, Marques MT (2012) Criado Laboratório para Produzir Biossimilares no Brasil. Soc Bra Reum.

59. Schwanke RC, Renard G, Chies JM, Campos MM, Batista EL Jr, et al. (2009) Molecular cloning, expression in Escherichia coli and production of bioactive homogeneous recombinant human granulocyte and macrophage colony stimulating factor. Int J Biol Macromol 45: 97-102.

60. Novo JB, Oliveira ML, Magalhães GS, Morganti L, Raw I, et al. (2010) Generation of polyclonal antibodies against recombinant human glucocerebrosidase produced in Escherichia coli. Mol Biotechnol 46: 279-286.

61. Gomes FR, Maluenda AC, Tápias JO, Oliveira FL, Sá-Rocha LC, et al. (2012 Expression of recombinant human mutant granulocyte colony stimulating factor (Nartograstim) in Escherichia coli. World J Microbiol Biotechnol 28: 2593-2600.

62. Vigani AG, Goçales ES, Pavan MH, Genari F, Tozzo R, et al. (2012) Therapeutic effectiveness of biosimilar standard interferon versus pegylated interferon for chronic hepatitis C genotypes 2 or 3. Braz J Infect Dis 16: 232-236.

63. Martins de Sa C, Grossi de Sa MF, Akhayat O, Broders F, Scherrer K, et al (1986) Prosomes. Ubiquity and inter-species structural variation. J Mol Biol 187: 479-493. 